\title{
STUDY ON THE USE OF ELECTRICAL DEVICES IN SMART SPACES: PROFESSIONAL ENVIRONMENT VERSUS PERSONAL ENVIRONMENT
}

\author{
A. Ș. PICA, LAURA MARCU, M. V. PICA \\ Politehnica University of Bucharest, Valahia University of Targoviste \\ E-mail: stefan.pica@cyberservices.com, laura_marcu_uvt@yahoo.fr,picamihai@gmail.com
}

\begin{abstract}
The article addresses the issue of the attitude of Romanian consumer regarding the electrical devices that can be used at work and at home. In the context of the growing interest for these devices worldwide, the question arises what is the interest of the Romanian consumer for such devices. The research is built on a case study and uses as a method of analysis the quantitative study with questionnaire, highlighting the level of acceptance in use of different categories of electrical devices, advantages that characterize the perception of the Romanian consumer.
\end{abstract}

Keywords: consumer, electrical devices, internet of things (IoT), smart space

\section{INTRODUCTION}

The Internet of Things (IoT) is one of the areas where market growth forecasts are strongly optimistic. According to a study conducted by Business Insider Intelligence, the cumulative investments worldwide would amount to about $\$ 15$ trillion in the period 2017 2025 as a result of accelerating the interest of companies to invest in such solutions. Consequently, more than 55 billion devices connected to Internet of Things are expected worldwide in 2025 , about 9 billion more than in 2017 [4].

In Romania, the smart device market is still in its infancy. The first steps have been taken, so there are suppliers and store with ,smart" products, from smart bulbs to automatic thermostats and remotely controllable sockets. The idea of smart devices is meant to bring multiple benefits both at work and at home.

In terms of advantages at home, there are benefits in security, synergy efficiency, comfort, aspects that cannot be ignored. However, the concept of ,,smart space" also includes a number of constraints, the most often mentioned being the need to design the space to consider these devices and, implicitly, the associated costs, he need for specialized personnel to install the devices, but also the need for additional security against potential hackers given that "smart space" involve connecting to the internet [7]. On the other hand, devices currently use the equipment manufacturer's own standard and must be controlled by a different application on the smartphone, which greatly complicates a person's activity when there are several devices, controlled by different applications.
From the point of view of companies, the interest is even greater, the adoption of such solutions being considered a premise for reducing costs, better monitoring of processes and optimization of resources. Therefore, the solutions that allow the automatisation of different activities in a company or in-house processes are the main segments of the IoT market [5].

\section{PURPOSE AND METHODOLOGY OF THE STUDY}

What is the opinion of consumers about these smart devices? According to a recent study conducted by Ericsson Research on the most advanced people on adoption of new technologies and living in 15 major cities, consumers assigned 10 main roles that these smart devices should play in the future, respectively by 2030 . Among them including contributions to the safety and protection of the individual, warning in case of extreme events, connection and interconnection, content creation [3].

The question is what is the interest of the Romanian consumer for these smart devices, especially since the degree of urbanization and technical equipment in Romania is not as high as in developed countries. For that reason, this study aims to evaluate comparatively the extent to which electrical devices are used in the professional activity or in the personal living environment of Romanian employees.

We start from the definition of intelligent space, respectively an automated space that includes the control and computerization of lighting, heating, ventilation and security, as well as household items. Such devices, when observed and controlled remotely, are an essential element of the new technology called the "Internet of Things", which involves the two-way exchange of data and information via the Internet. These devices specific to a "smart space" involves automation and remote control, aspects related to human safety, environmental comfort and reduction of consumption.

We opted for a case study in an entity operating in Romania, with Romanian employees. In this sense, a public institution in the financial field with a number of 50 employees was chosen. For the analysis, a quantitative study was used, based on a questionnaire, in which all employees of that entity were included. The advantage of total research of all employees is to provide a 
comprehensive picture of the entity-level perception of those devices [6].

The objectives of our study were:

1. Comparison between the degree of acceptance of the use of electrical devices specific to "smart space" at work and at the home of respondents;

2. Knowing the employees' perception of the advantages and brakes of electrical devices specific to "smart space" regarding their use in both situations;

3. Observing the existence of differences in terms of socio-demographic criteria regarding openness to the use of electrical devices.

The questionnaire was structured in three parts, in line with the proposed objectives and used only closed questions, including scales to measure the degree of acceptability of respondents. The answers were collected in the first part of September 2020, by face-to-face administration, so the non-response rate was $0 \%$ and incomplete questionnaires were avoided [1]. The processing and analysis used the SPSS program.

\section{ACCEPTABILITY OF THE USE OF ELECTRICAL DEVICES AT WORK AND AT HOME}

Respondents were presented with a list of categories of electrical devices, being asked to indicate, through two separate questions, which of them should be used at work and at home. Out of the total of 50 respondents, most indicated in the first places as a utility at work were fire detectors $(86 \%)$, video surveillance of vulnerable areas $(74 \%)$, burglar alarms $(66 \%)$ and detectors of movement in case of burglary (64\%). Among the most useful devices for the home were fire detectors (54\%), video surveillance of vulnerable areas (46\%), burglar alarms $(39 \%)$ and remote temperature control devices (39\%) (Figure 1). The difference observed between the two situations refers primarily to the lower interest in using these devices in the home. Secondly, there is a more frequent mention of devices that ensure safety in the workplace, compared to home, where safety is complemented by the interest in comfort [9].

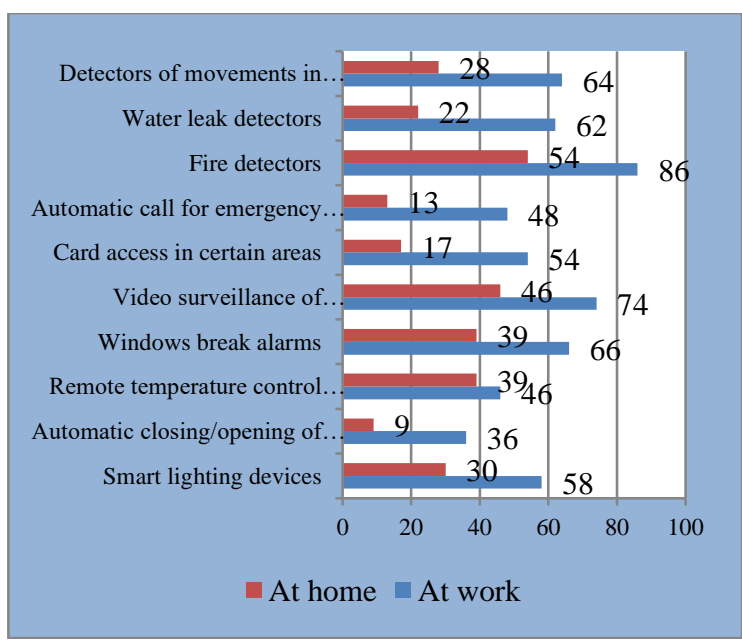

Figure 1. Devices specific to a "smart space" useful in the institution and at home (\%)

Going further, we asked respondents to what extent they are willing to actually use the "smart space" devices in the workplace and at home. The response was measured using the three-step semantic differential scale (1 - not at all interested, 2 - few interested, 3 - very interested). Regarding the workplace, the best degree of acceptability was recorded by video surveillance devices of vulnerable areas (score 2.4 out of 3 , respectively "average interest") and smart lighting devices (score 2.3 / 3, i.e., "average interest"). Devices for automatic calling of emergency services and those which allow card access in certain areas received scores close to 2 (out of 3 ), which indicates a "low interest", while remote temperature control devices and those for automatic closing / opening of some equipment obtained scores below 2, respectively a very low interest (Figure 2).

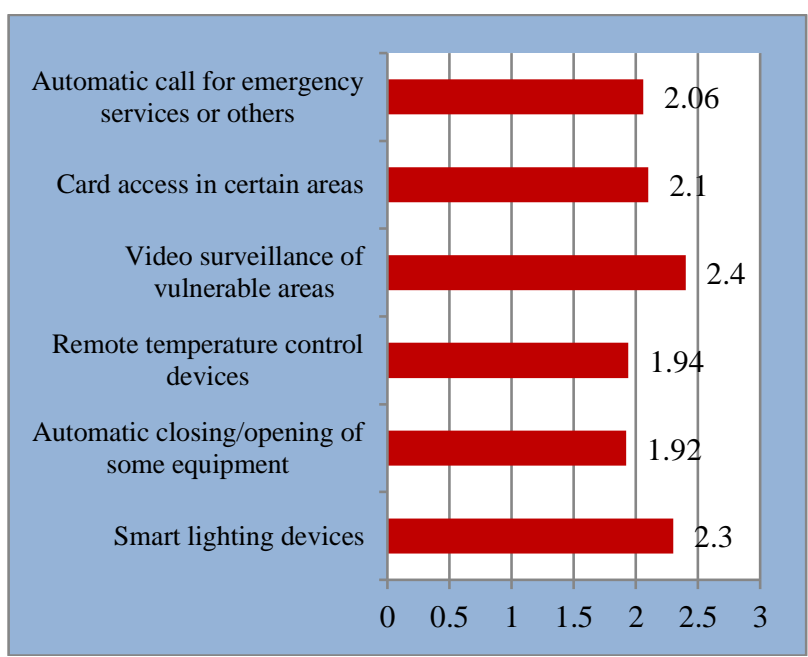

Figure 2. Acceptability score of using devices of a "smart space" at work

In terms of home use, the scores obtained indicate a greater interest in use. Thus, the detectors of fire, water leaks, movement in case of burglary and video surveillance devices of vulnerable areas obtained scores between 2.5 and 3 (maximum value), respectively a level of "medium to high interest". Window burglar alarms, smart lighting devices and remote temperature controls have a degree of "medium interest"; the automatic call of the emergency services has a "low interest", while the automatic closing / opening of some equipment and the access with the card in certain areas have a "very low" interest (Figure 3). 


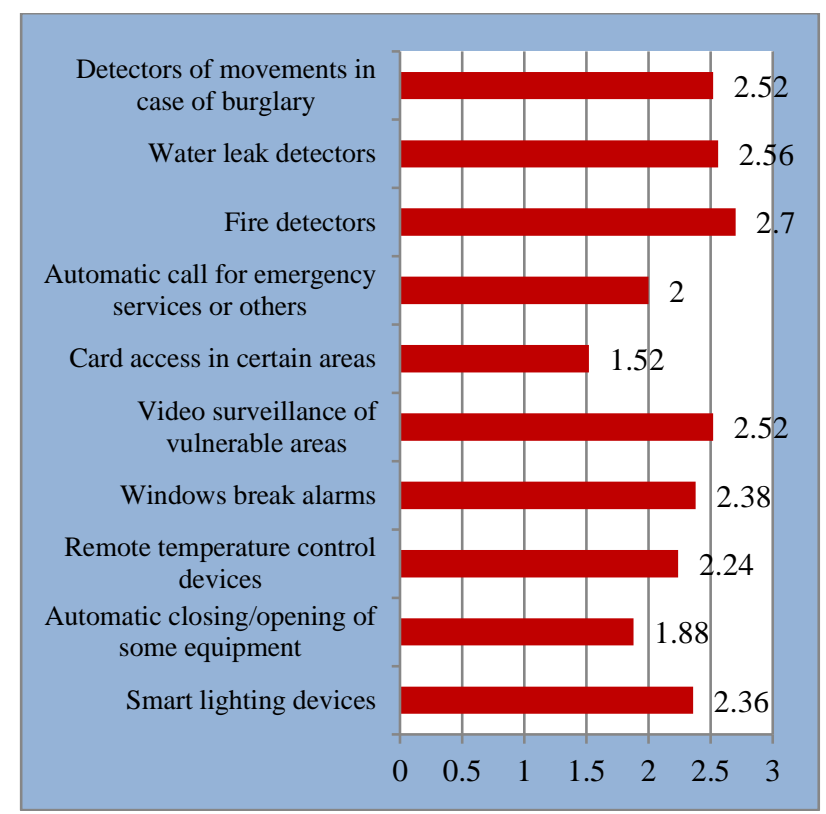

Figure 3. Acceptability score of using devices of a "smart space" at work.

\section{EMPLOYEE PERCEPTION OF THE ADVANTAGES AND DISADVANTAGES OF DEVICES SPECIFIC TO A "SMART SPACE"}

Asked about the main advantages of using devices specific to a "smart space", respondents indicated primarily the protection of the building, equipment and data, both at work and at home (Figure 4).

Major differences in the perception of benefits for the two environments of use (work and home) are observed in terms of "remote control of equipment" and "safety at work" (devices are perceived as advantageous to these criteria mainly for use at home) and "increased comfort at work" (criterion evoked as an advantage especially at work).

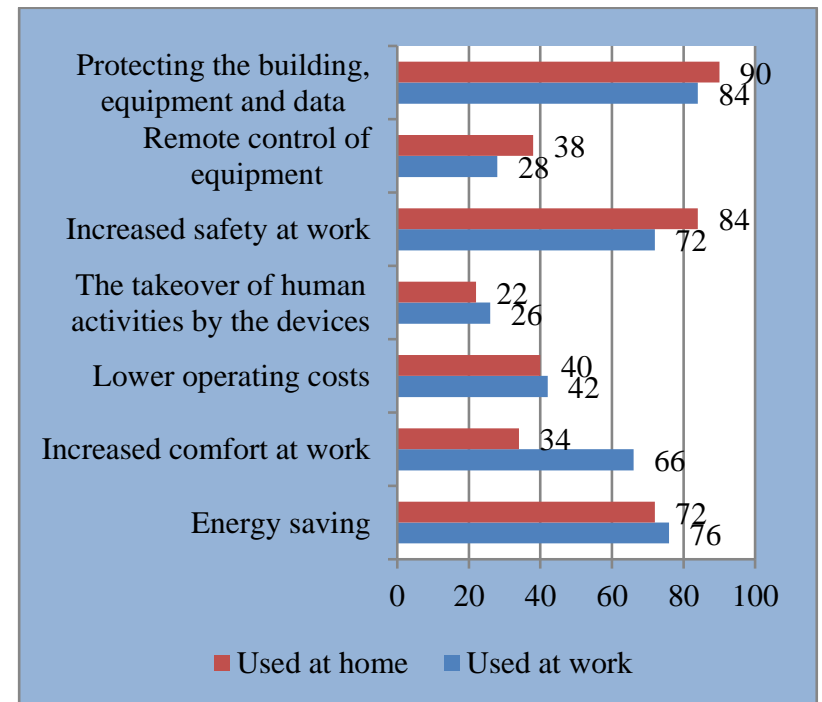

Figure 4. Advantages of devices specific to a "smart space" (\%)
Regarding the disadvantages of devices specific to a "smart space", $28 \%$ of respondents did not identify a disadvantage in the case of use at work and $16 \%$ in the case of use at home. Of the $72 \%$ of respondents who mentioned disadvantages, the main reasons why they do not want to use devices specific to a "smart space" at work are costs $(75 \%$ considering that these devices involve too much investment) and "lack of usefulness in relation to the activity carried out at the workplace" $(19 \%)$. Other reasons cited, with a lower frequency, were "lack of confidence in the efficiency of the devices" $(8 \%)$ and "difficulty in using them technically" (3\%) (Figure 5).

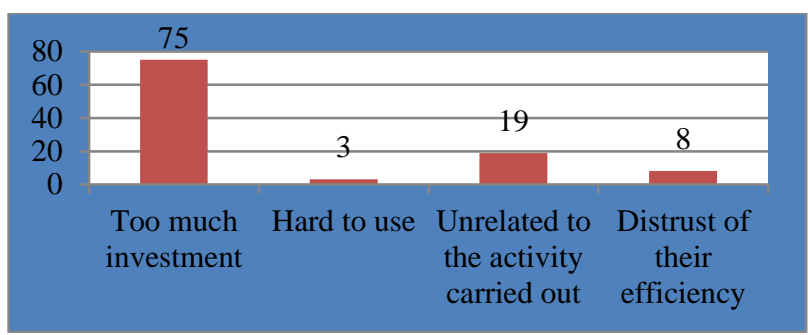

Figure 5. Brakes in the use of devices specific to a "smart space" in the workplace (\%)

In the case of home use, the main arguments against devices specific to a "smart space" were the costs (90\% of respondents consider it too much investment) and the difficulty or impossibility of implementing the devices due to the characteristics of the living space (19\%). Other reasons cited as brakes in the use of devices at home were "lack of confidence in their efficiency" (7\%) and "difficulties in using them technically" (2\%) (Figure 6).

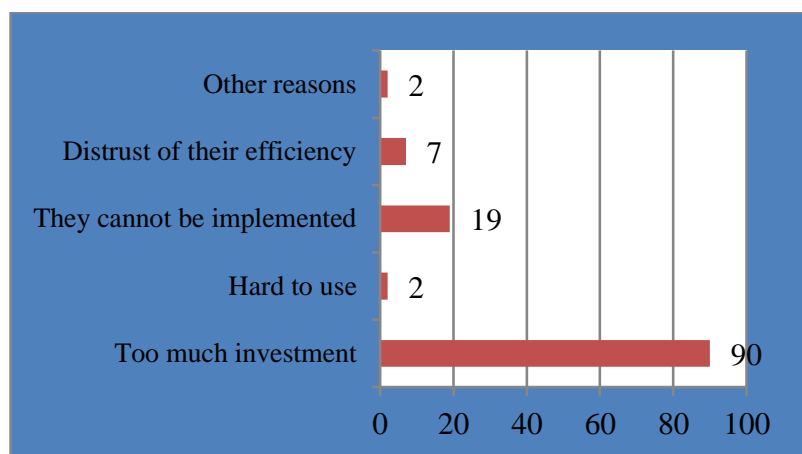

Figure 6. Brakes in the use of devices specific to a "smart space" at home $(\%)$

\section{THE INFLUENCE OF SOCIO-DEMOGRAPHIC CRITERIA ON INTEREST IN DEVICES SPECIFIC TO A "SMART SPACE"}

In order to study whether there are socio-demographic factors that can influence the openness of individuals to the use of devices, we introduced in the questionnaire a number of elements specific to the respondent's profile: sex, level of education, field of study, age, type of domicile [8]. To these, we added a question related to the type of function performed at work (management or execution). Based on these criteria, the following structure of respondents was obtained:

- $\quad$ By sex: $42 \%$ men, $58 \%$ women; 
- Depending on the level of studies completed: $33 \%$ university studies and $67 \%$ post-university studies;

- Depending on the field of study completed: $58 \%$ economic, $19 \%$ legal, $23 \%$ technical;

- Depending on age: $12.5 \%$ under 35 years, $27 \%$ between $35-45$ years, $48 \%$ between $46-55$ years, $12.5 \%$ over 55 years;

- Depending on the domicile: $73 \%$ live in a block of flats and $27 \%$ in a house.

- By type of position exercised in the analysed institution: $12.5 \%$ management positions and $87.5 \%$ executive functions.

The analysis on the subcategories of respondents created based on these criteria was performed using the chi-square significance test. The application of this test aimed to determine whether one or more of the socio-demographic criteria exerts an influence on the opinion of individuals regarding the usefulness of the devices studied, their advantages, as well as the degree of acceptability and the actual intention to use at work or at home. Its chi-square values, obtained statistically, indicate the degree of dependence of the phenomenon analysed by the sociodemographic criterion taken into account [2].

Regarding the respondents' opinion on the usefulness of devices specific to "smart space" at work or at home (Figure 1), the chi-square values indicate an "insignificant dependence" on socio-demographic criteria, i.e., these criteria does not influence the opinion about the usefulness of the devices at all. The same result ("insignificant dependence") was obtained regarding the testing of the relationship between the brakes evoked in the use of devices at work and at home (Figure 5 and Figure 6) and the criteria analysed. In the case of the relationship between the advantages attributed to the devices and the socio-demographic criteria, chi-square indicates a "slightly significant dependence" on the "level of education" of the respondents and the lack of dependence on the other criteria, both in use at work and at home (Table 1).

Table 1. Results of chi-square test in case of questions about electrical devices specific to „smart space” regarded as a whole.

\begin{tabular}{|c|c|c|c|c|c|c|}
\hline $\begin{array}{l}\text { Criterion } \\
\text { Opinion }\end{array}$ & Sex & $\begin{array}{l}\text { Level } \\
\text { of } \\
\text { educa } \\
\text { tion }\end{array}$ & $\begin{array}{c}\text { Fiel } \\
\mathrm{d} \text { of } \\
\text { stud } \\
\text { ies }\end{array}$ & Age & $\begin{array}{l}\text { Reside } \\
\text { nce }\end{array}$ & $\begin{array}{l}\text { Positi } \\
\text { on in } \\
\text { comp } \\
\text { any }\end{array}$ \\
\hline $\begin{array}{l}\text { Utility of } \\
\text { devices } \\
\text { at work }\end{array}$ & $\begin{array}{c}5.05 \\
*\end{array}$ & $1.99 *$ & $\begin{array}{c}7.19 \\
*\end{array}$ & $\begin{array}{c}6.63 \\
*\end{array}$ & $1.61 *$ & $6.55^{*}$ \\
\hline $\begin{array}{l}\text { Advanta } \\
\text { ges of } \\
\text { devices } \\
\text { at work }\end{array}$ & $\begin{array}{c}0.59 \\
*\end{array}$ & $\begin{array}{c}10.50 \\
* *\end{array}$ & $\begin{array}{c}5.76 \\
*\end{array}$ & $\begin{array}{c}5.58 \\
*\end{array}$ & $0.84 *$ & $4.66 *$ \\
\hline $\begin{array}{l}\text { Disadvan } \\
\text { tages of } \\
\text { devices } \\
\text { at work }\end{array}$ & $\begin{array}{c}2.51 \\
*\end{array}$ & $1.95^{*}$ & $\begin{array}{c}7.91 \\
*\end{array}$ & $\begin{array}{c}12.0 \\
2 *\end{array}$ & $3.47 *$ & $2.81 *$ \\
\hline
\end{tabular}

\begin{tabular}{|l|c|c|c|c|c|c|}
\hline $\begin{array}{l}\text { Utility of } \\
\text { devices } \\
\text { at home }\end{array}$ & $\begin{array}{c}11.1 \\
1 *\end{array}$ & $\begin{array}{c}10.18 \\
*\end{array}$ & $\begin{array}{c}8.34 \\
*\end{array}$ & $\begin{array}{c}25.9 \\
4 *\end{array}$ & $8.06 *$ & $3.82 *$ \\
\hline $\begin{array}{l}\text { Advanta } \\
\text { ges of } \\
\text { devices } \\
\text { at home }\end{array}$ & $\begin{array}{c}1.91 \\
*\end{array}$ & $\begin{array}{c}10.50 \\
* *\end{array}$ & $\begin{array}{c}1.92 \\
*\end{array}$ & $\begin{array}{c}8.62 \\
*\end{array}$ & $0.22 *$ & $2.46^{*}$ \\
\hline $\begin{array}{l}\text { Disadvan } \\
\text { tages of } \\
\text { devices } \\
\text { at home }\end{array}$ & 4.77 & 1.95 & 7.91 & 8.80 & 6.91 & 0.41 \\
\hline
\end{tabular}

Remarque: * Insignificant dependence; ** Slightly significant dependence

If the questions did not indicate significant differences according to the socio-demographic criteria for the questions that referred to all the categories of devices specific to the "smart space", the situation is much more nuanced in the case of questions that targeted a single category of devices.

Table 2. Chi-square test and dependency level regarding the acceptance of the use of devices at work

\begin{tabular}{|c|c|c|c|c|c|c|}
\hline & Sex & $\begin{array}{l}\text { Resid } \\
\text { ence }\end{array}$ & Age & $\begin{array}{l}\text { Level } \\
\text { of } \\
\text { educa } \\
\text { tion }\end{array}$ & $\begin{array}{c}\text { Field } \\
\text { of } \\
\text { studi } \\
\text { es }\end{array}$ & $\begin{array}{c}\text { Positi } \\
\text { on in } \\
\text { comp } \\
\text { any }\end{array}$ \\
\hline $\begin{array}{l}\text { Smart } \\
\text { lightin } \\
\mathrm{g} \\
\text { device } \\
\mathrm{s} \\
\end{array}$ & $\begin{array}{c}1.43 \\
\text { Insig } \\
\text { nifica } \\
\text { nt }\end{array}$ & $\begin{array}{c}4.48 \\
\text { Sligh } \\
\text { tly } \\
\text { signif } \\
\text { icant }\end{array}$ & $\begin{array}{c}4.77 \\
\text { Insig } \\
\text { nifica } \\
\text { nt }\end{array}$ & $\begin{array}{c}0.19 \\
\text { Insig } \\
\text { nifica } \\
\text { nt }\end{array}$ & $\begin{array}{c}7.71 \\
\text { Sligh } \\
\text { tly } \\
\text { signif } \\
\text { icant }\end{array}$ & $\begin{array}{c}14.94 \\
\text { Very } \\
\text { signif } \\
\text { icant }\end{array}$ \\
\hline $\begin{array}{l}\text { Autom } \\
\text { atic } \\
\text { closing } \\
\text { /openi } \\
\text { ng of } \\
\text { some } \\
\text { equip } \\
\text { ment }\end{array}$ & $\begin{array}{c}1.99 \\
\text { Insig } \\
\text { nifica } \\
\text { nt }\end{array}$ & $\begin{array}{c}0.82 \\
\text { Insig } \\
\text { nifica } \\
\text { nt }\end{array}$ & $\begin{array}{c}2.07 \\
\text { Insig } \\
\text { nifica } \\
\text { nt }\end{array}$ & $\begin{array}{c}2.36 \\
\text { Insig } \\
\text { nifica } \\
\text { nt }\end{array}$ & $\begin{array}{c}4.92 \\
\text { Insig } \\
\text { nifica } \\
\text { nt }\end{array}$ & $\begin{array}{c}2.35 \\
\text { Insig } \\
\text { nifica } \\
\text { nt }\end{array}$ \\
\hline $\begin{array}{l}\text { Remot } \\
\mathrm{e} \\
\text { temper } \\
\text { ature } \\
\text { control } \\
\text { device } \\
\mathrm{s} \\
\end{array}$ & $\begin{array}{c}3.68 \\
\text { Insig } \\
\text { nifica } \\
\text { nt }\end{array}$ & $\begin{array}{c}0.78 \\
\text { Insig } \\
\text { nifica } \\
\text { nt }\end{array}$ & $\begin{array}{c}3.85 \\
\text { Insig } \\
\text { nifica } \\
\text { nt }\end{array}$ & $\begin{array}{c}1.77 \\
\text { Insig } \\
\text { nifica } \\
\text { nt }\end{array}$ & $\begin{array}{c}1.51 \\
\text { Insig } \\
\text { nifica } \\
\text { nt }\end{array}$ & $\begin{array}{c}0.64 \\
\text { Insig } \\
\text { nifica } \\
\text { nt }\end{array}$ \\
\hline $\begin{array}{l}\text { Video } \\
\text { surveil } \\
\text { lance } \\
\text { of } \\
\text { vulner } \\
\text { able } \\
\text { areas }\end{array}$ & $\begin{array}{c}1.97 \\
\text { Insig } \\
\text { nifica } \\
\text { nt }\end{array}$ & $\begin{array}{c}2.84 \\
\text { Insig } \\
\text { nifica } \\
\text { nt }\end{array}$ & $\begin{array}{c}4.52 \\
\text { Insig } \\
\text { nifica } \\
\text { nt }\end{array}$ & $\begin{array}{c}2.48 \\
\text { Insig } \\
\text { nifica } \\
\text { nt }\end{array}$ & $\begin{array}{c}4.78 \\
\text { Insig } \\
\text { nifica } \\
\text { nt }\end{array}$ & $\begin{array}{c}1.38 \\
\text { Insig } \\
\text { nifica } \\
\text { nt }\end{array}$ \\
\hline $\begin{array}{l}\text { Card } \\
\text { access } \\
\text { in } \\
\text { certain } \\
\text { areas }\end{array}$ & $\begin{array}{c}3.84 \\
\text { Sligh } \\
\text { tly } \\
\text { signif } \\
\text { icant }\end{array}$ & $\begin{array}{c}0.41 \\
\text { Insig } \\
\text { nifica } \\
\text { nt }\end{array}$ & $\begin{array}{c}11.88 \\
\text { Sligh } \\
\text { tly } \\
\text { signif } \\
\text { icant }\end{array}$ & $\begin{array}{l}10.18 \\
\text { Very } \\
\text { signif } \\
\text { icant }\end{array}$ & $\begin{array}{c}2.26 \\
\text { Insig } \\
\text { nifica } \\
\text { nt }\end{array}$ & $\begin{array}{c}4.01 \\
\text { Sligh } \\
\text { tly } \\
\text { signif } \\
\text { icant } \\
\end{array}$ \\
\hline $\begin{array}{l}\text { Autom } \\
\text { atic } \\
\text { call for } \\
\text { emerge } \\
\text { ncy } \\
\text { service }\end{array}$ & $\begin{array}{c}4.36 \\
\text { Sligh } \\
\text { tly } \\
\text { signif } \\
\text { icant }\end{array}$ & $\begin{array}{c}2.04 \\
\text { Insig } \\
\text { nifica } \\
\text { nt }\end{array}$ & $\begin{array}{l}13.68 \\
\text { Signi } \\
\text { ficant }\end{array}$ & $\begin{array}{c}1.27 \\
\text { Insig } \\
\text { nifica } \\
\text { nt }\end{array}$ & $\begin{array}{c}8.73 \\
\text { Sligh } \\
\text { tly } \\
\text { signif } \\
\text { icant }\end{array}$ & $\begin{array}{c}2.49 \\
\text { Insig } \\
\text { nifica } \\
\text { nt }\end{array}$ \\
\hline
\end{tabular}




\begin{tabular}{|l|l|l|l|l|l|l|}
\hline $\begin{array}{l}\text { s or } \\
\text { others }\end{array}$ & & & & & & \\
\hline
\end{tabular}

Table 2 summarizes the results of the chi-square test and the degree of dependency applied to questions about the interest in really using the devices in the workplace. By applying the chi-square significance test for each sociodemographic criterion, it was found:

a) The absence of the influence of the sociodemographic criteria analysed on the interest of using at work "Devices for automatic closing / opening of equipment", "Remote temperature control devices", "Devices for video surveillance of vulnerable areas";

b) The existence of an influence of the sociodemographic criteria on the interest of using devices in the workplace, as follows:

- Smart lighting devices: "insignificant dependence" on the criteria "home" and "field of study". In this situation, of "insignificant dependence", it is not necessary to consider the existence of different segments of individuals. On the other hand, the chisquare test showed a "very significant" dependence on the "type of function" criterion, respectively a lower interest of people with a leading position towards these devices.

- Card access: "insignificant dependence" on the criteria "sex", "age", "type of function", "very significant dependence" on the criterion "level of education" where the results show that people with postgraduate studies are more interested in these devices than those with a university degree.

- Automatic calling of emergency services or other services: "insignificant dependence" on the criteria "sex" and "field of study", "significant dependence" on the criterion "age", respectively a low interest for the category over 56 years and high interest in the 35 45 years category (compared to the theoretical values determined by the chi-square test).

In table 3 are centralized the results of the application of the chi-square significance test for the questions regarding the interest to use at home one of the categories of devices specific to "smart space". According to them, for four of the device categories ("Intelligent lighting devices", "Automatic closing / opening of equipment", "Remote temperature control devices", "Motion detectors in case of burglary") none of the socio-demographic criteria it does not have an influence on the interest of their use, and for the category "Video surveillance of vulnerable areas" only the criterion "home" has a dependency, but of a "little significant" level.

A notable dependence on one or two of the sociodemographic criteria is noted in the following categories of devices:

- Burglar alarms: "insignificant dependence" on the "sex" criterion, "significant dependence" on the "domicile" criterion, respectively a greater interest of the respondents living in the house, compared to those living in the block;
Access by card in certain areas: "insignificant dependence" on the criterion "domicile", "significant dependence" on the criterion "level of education", people with university studies being more interested compared to those with post-university studies;

- Automatic call for emergency services or other services: "insignificant dependence" on the criterion "level of education", "very significant dependence" on the criterion "field of study", the category of respondents with legal studies being particularly interested.

- Fire detectors: "significant dependence" on the "sex" criterion, women being more interested than men;

- Water leak detectors: "very significant dependence" on the "sex" criterion (women being more interested than men and the "age" criterion (category "56 years and over" being very little interested in these devices).

Table 3. Chi-square test and dependency level regarding the acceptance of the use of devices at home

\begin{tabular}{|c|c|c|c|c|c|c|}
\hline & Sex & $\begin{array}{l}\text { Resid } \\
\text { ence }\end{array}$ & Age & $\begin{array}{l}\text { Level } \\
\text { of } \\
\text { educa } \\
\text { tion }\end{array}$ & $\begin{array}{l}\text { Field } \\
\text { of } \\
\text { studi } \\
\text { es }\end{array}$ & $\begin{array}{c}\text { Positi } \\
\text { on in } \\
\text { comp } \\
\text { any }\end{array}$ \\
\hline $\begin{array}{l}\text { Smart } \\
\text { lightin } \\
\mathrm{g} \\
\text { device } \\
\mathrm{s}\end{array}$ & $\begin{array}{c}3,47 \\
\text { Insig } \\
\text { nifica } \\
\text { nt }\end{array}$ & $\begin{array}{c}0,91 \\
\text { Insig } \\
\text { nifica } \\
\text { nt }\end{array}$ & $\begin{array}{c}5,31 \\
\text { Insig } \\
\text { nifica } \\
\text { nt }\end{array}$ & $\begin{array}{c}1,25 \\
\text { Insig } \\
\text { nifica } \\
\text { nt }\end{array}$ & $\begin{array}{c}0,90 \\
\text { Insig } \\
\text { nifica } \\
\text { nt }\end{array}$ & $\begin{array}{c}0,42 \\
\text { Insig } \\
\text { nifica } \\
\text { nt }\end{array}$ \\
\hline $\begin{array}{l}\text { Autom } \\
\text { atic } \\
\text { closing } \\
\text { /openi } \\
\text { ng of } \\
\text { some } \\
\text { equip } \\
\text { ment }\end{array}$ & $\begin{array}{c}1.40 \\
\text { Insig } \\
\text { nifica } \\
\text { nt }\end{array}$ & $\begin{array}{c}0.22 \\
\text { Insig } \\
\text { nifica } \\
\text { nt }\end{array}$ & $\begin{array}{c}0.97 \\
\text { Insig } \\
\text { nifica } \\
\text { nt }\end{array}$ & $\begin{array}{c}1.58 \\
\text { Insig } \\
\text { nifica } \\
\text { nt }\end{array}$ & $\begin{array}{c}2.78 \\
\text { Insig } \\
\text { nifica } \\
\text { nt }\end{array}$ & $\begin{array}{c}2.27 \\
\text { Insig } \\
\text { nifica } \\
\text { nt }\end{array}$ \\
\hline $\begin{array}{l}\text { Remot } \\
\mathrm{e} \\
\text { temper } \\
\text { ature } \\
\text { control } \\
\text { device } \\
\mathrm{s} \\
\end{array}$ & $\begin{array}{c}2.26 \\
\text { Insig } \\
\text { nifica } \\
\text { nt }\end{array}$ & $\begin{array}{c}0.50 \\
\text { Insig } \\
\text { nifica } \\
\text { nt }\end{array}$ & $\begin{array}{c}6.78 \\
\text { Insig } \\
\text { nifica } \\
\text { nt }\end{array}$ & $\begin{array}{c}1.36 \\
\text { Insig } \\
\text { nifica } \\
\text { nt }\end{array}$ & $\begin{array}{c}4.04 \\
\text { Insig } \\
\text { nifica } \\
\text { nt }\end{array}$ & $\begin{array}{c}2.40 \\
\text { Insig } \\
\text { nifica } \\
\text { nt }\end{array}$ \\
\hline $\begin{array}{l}\text { Windo } \\
\text { ws } \\
\text { break } \\
\text { alarms }\end{array}$ & $\begin{array}{c}4.30 \\
\text { Sligh } \\
\text { tly } \\
\text { signif } \\
\text { icant }\end{array}$ & $\begin{array}{c}6.14 \\
\text { Signi } \\
\text { ficant }\end{array}$ & $\begin{array}{c}3.88 \\
\text { Insig } \\
\text { nifica } \\
\text { nt }\end{array}$ & $\begin{array}{c}1.09 \\
\text { Insig } \\
\text { nifica } \\
\text { nt }\end{array}$ & $\begin{array}{c}1.60 \\
\text { Insig } \\
\text { nifica } \\
\text { nt }\end{array}$ & $\begin{array}{c}0.26 \\
\text { Insig } \\
\text { nifica } \\
\text { nt }\end{array}$ \\
\hline $\begin{array}{l}\text { Video } \\
\text { surveil } \\
\text { lance } \\
\text { of } \\
\text { vulner } \\
\text { able } \\
\text { areas }\end{array}$ & $\begin{array}{c}2.20 \\
\text { Insig } \\
\text { nifica } \\
\text { nt }\end{array}$ & $\begin{array}{c}4.83 \\
\text { Sligh } \\
\text { tly } \\
\text { signif } \\
\text { icant }\end{array}$ & $\begin{array}{c}2.82 \\
\text { Insig } \\
\text { nifica } \\
\text { nt }\end{array}$ & $\begin{array}{c}0.00 \\
\text { Insig } \\
\text { nifica } \\
\text { nt }\end{array}$ & $\begin{array}{c}4, .47 \\
\text { Insig } \\
\text { nifica } \\
\text { nt }\end{array}$ & $\begin{array}{c}1.09 \\
\text { Insig } \\
\text { nifica } \\
\text { nt }\end{array}$ \\
\hline $\begin{array}{l}\text { Card } \\
\text { access } \\
\text { in } \\
\text { certain } \\
\text { areas }\end{array}$ & $\begin{array}{c}1.33 \\
\text { Insig } \\
\text { nifica } \\
\text { nt }\end{array}$ & $\begin{array}{c}5.12 \\
\text { Sligh } \\
\text { tly } \\
\text { signif } \\
\text { icant }\end{array}$ & $\begin{array}{c}8.80 \\
\text { Insig } \\
\text { nifica } \\
\text { nt }\end{array}$ & $\begin{array}{c}8.20 \\
\text { Signi } \\
\text { ficant }\end{array}$ & $\begin{array}{c}1.62 \\
\text { Insig } \\
\text { nifica } \\
\text { nt }\end{array}$ & $\begin{array}{c}1.43 \\
\text { Insig } \\
\text { nifica } \\
\text { nt }\end{array}$ \\
\hline $\begin{array}{l}\text { Autom } \\
\text { atic } \\
\text { call for }\end{array}$ & 2.35 & 3.41 & 7.27 & $\begin{array}{l}5.54 \\
\text { Sligh }\end{array}$ & 15.15 & 2.13 \\
\hline
\end{tabular}




\begin{tabular}{|l|c|c|c|c|c|c|}
\hline $\begin{array}{l}\text { emerge } \\
\text { ncy } \\
\text { service } \\
\text { s or } \\
\text { others }\end{array}$ & $\begin{array}{c}\text { Insig } \\
\text { nifica } \\
\text { nt }\end{array}$ & $\begin{array}{c}\text { Insig } \\
\text { nifica } \\
\text { nt }\end{array}$ & $\begin{array}{c}\text { Insig } \\
\text { nifica } \\
\text { nt }\end{array}$ & $\begin{array}{c}\text { tly } \\
\text { signif } \\
\text { icant }\end{array}$ & $\begin{array}{c}\text { Very } \\
\text { signif } \\
\text { icant }\end{array}$ & $\begin{array}{c}\text { Insig } \\
\text { nifica } \\
\text { nt }\end{array}$ \\
\hline $\begin{array}{l}\text { Fire } \\
\text { detecto } \\
\text { rs }\end{array}$ & $\begin{array}{c}7.43 \\
\text { Signi } \\
\text { ficant }\end{array}$ & $\begin{array}{c}1.30 \\
\text { Insig } \\
\text { nifica } \\
\text { nt }\end{array}$ & $\begin{array}{c}5.29 \\
\text { Insig } \\
\text { nifica } \\
\text { nt }\end{array}$ & $\begin{array}{c}0.62 \\
\text { Insig } \\
\text { nifica } \\
\text { nt }\end{array}$ & $\begin{array}{c}1.58 \\
\text { Insig } \\
\text { nifica } \\
\text { nt }\end{array}$ & $\begin{array}{c}\text { Insig } \\
\text { nifica } \\
\text { nt }\end{array}$ \\
\hline $\begin{array}{l}\text { Water } \\
\text { leak } \\
\text { detecto } \\
\text { rs }\end{array}$ & $\begin{array}{c}9.39 \\
\text { Very } \\
\text { signif } \\
\text { icant }\end{array}$ & $\begin{array}{c}1.74 \\
\text { Insig } \\
\text { nifica } \\
\text { nt }\end{array}$ & $\begin{array}{c}17.76 \\
\text { Very } \\
\text { signif } \\
\text { icant }\end{array}$ & $\begin{array}{c}0.12 \\
\text { Insig } \\
\text { nifica } \\
\text { nt }\end{array}$ & $\begin{array}{c}3.68 \\
\text { Insig } \\
\text { nifica } \\
\text { nt }\end{array}$ & $\begin{array}{c}\text { Insig } \\
\text { nifica } \\
\text { nt }\end{array}$ \\
\hline $\begin{array}{l}\text { Detect } \\
\text { ors of } \\
\text { move } \\
\text { ments } \\
\text { in case } \\
\text { of }\end{array}$ & $\begin{array}{c}0.82 \\
\text { Insig } \\
\text { nifica } \\
\text { nt }\end{array}$ & $\begin{array}{c}0.77 \\
\text { Insig } \\
\text { nifica } \\
\text { nt }\end{array}$ & $\begin{array}{c}5.55 \\
\text { Insig } \\
\text { nifica } \\
\text { nt }\end{array}$ & $\begin{array}{c}0.54 \\
\text { Insig } \\
\text { nifica } \\
\text { nt }\end{array}$ & $\begin{array}{c}1.31 \\
\text { Insig } \\
\text { nifica } \\
\text { nt }\end{array}$ & $\begin{array}{c}0.02 \\
\text { Insig } \\
\text { nifica } \\
\text { nt }\end{array}$ \\
& & & & & & \\
\hline
\end{tabular}

\section{CONCLUSIONS}

Our study specifically aimed to analyse the perception of Romanians towards the use of electrical devices specific to "smart space". Being an exploratory study, we opted for a case study, based on the quantitative method of the survey with a questionnaire to collect the opinions of individuals. We chose to apply the survey to all employees in an entity so that we have a comprehensive view of the situation in that entity and the possibility of comparing the use of devices at work and at home.

The main limitations of the study lie in the nature of the chosen entity, so that we cannot consider that the results can be applied in an entity where the use of these devices is more frequent. Instead, the results may be a reference for other entities that have not implemented such devices and intend to use them.

The study shows an openness of people to the use of these devices, especially in the workplace, the interest in using them at home being hampered mainly by the perception of the investment calibre.

Socio-demographic analysis indicates the existence of some categories of employee that show a greater openness to devices specific to the "smart space", aspects that can be capitalized in the context of campaigns to promote the benefits of these devices in different market segments.

\section{REFERENCES}

[1] Nazmiye Balta-Ozkana, Benjamin Botelerb, Oscar Amerighic, European smart home market development: Public views on technical and economic aspects across the United Kingdom, Germany and Italy from Energy Research \& Social Science 3 (2014).

[2] Rohit Kadam, Pranav Mahamuni, Yash Parikh, Smart Home System from International Journal of
Innovative Research in Advanced Engineering ISSN: 2349-2163 (January 2015).

[3] Rehman S. Solar radiation over Saudi Arabia and comparisons with empirical models. Energy 1998; 23(12): 1077-1082.

[4] Ericsson, 10 HotConsumer Trends 2030, Connected intelligent machines (December 2020. pp. 1-16).

[5] Rotariu Traian. Iluț Petru, Survey and opinion poll. Theory and practice, Iași: Polirom (2001, p. 122).

[6] Fournis Yves, Les études de marché, Techniques d'enquête, sondages, interprétation des resultants. Paris: Dunod (3e édition, 1995, p. 74).

[7] P. Hamernik, P. Tanuska, D. Mudroncik, Classification of Functions in Smart Home from International Journal of Information and Education Technology (Vol. 2, April 2012).

[8] Christian Reinisch, Mario J. Kofler, Wolfgang Kastner, ThinkHome: A Smart Home as Digital Ecosystem from 4th IEEE International Conference on Digital Ecosystems and Technologies (2010).

[9] Gavard-Perret Marie-Laure, Gotteland David, Haon Christophe, Jolibert Alain, Méthodologie de la recherché. Paris: Pearson Education (2008. p. 282). 